\title{
ANALISIS KEPUASAN PENGGUNA SISTEM INFORMASI AKADEMIK DALAM PERSPEKTIF MANAJEMEN DI POLITEKNIK NEGERI SRIWIJAYA
}

\author{
Erlangga Kesuma Putra ${ }^{1}$, Darius Antoni ${ }^{2}$, Muhamad Akbar ${ }^{3}$ \\ 1,2,3 Universitas Bina Darma \\ ${ }^{1,2,3}$ Program Studi Magister Teknik Informatika \\ E-Mail : ${ }^{1 *}$ gonethekill@gmail.com, ${ }^{2}$ darius.antoni@ @inadarma.ac.id, \\ ${ }^{3}$ muhamad.akbar@binadarma.ac.id
}

Kepuasan Pengguna menjadi salah satu kunci dalam keberhasilan suatu Sistem Informasi. Penelitian ini bertujuan untuk menganalisis kepuasan Pengguna Sistem Informasi Akademik di Lingkungan Politeknik Negeri Sriwijaya berdasarkan variabel budaya organsasi dan kualitas sistem informasi terhadap kepuasaan pengguna sistem informasi dan implikasinya terhadap kinerja pegawai. Analisis data melibatkan 71 partisipan yang berasal dari tenaga kependidikan dengan variasi Jenis Kelamin, Usia, Pendidikan Terakhir dan Masa Kerja. Analisis data menggunakan Confirmatory Factor Analysis (CFA) Konstruk Eksogen dan Endogen serta SEM Partial Least Square (PLS). Hasil akhir didapatkan simpulan Variabel Budaya Organisasi berpengaruh positif dan tidak signifikan terhadap Kepuasan Penggunaan Sistem Informasi sedangkan variabel Kualitas Sistem Informasi berpengaruh positif dan signifikan terhadap Kepuasan Penggunaan Sistem Informasi Pegawai Politeknik Negeri Sriwijaya Palembang.

Kata Kunci - CIO, Kepuasan Pengguna, Sistem Informasi Manajemen

User's Satisfaction is one of the keys to the success of an Information System. This study aims to analyze the satisfaction of Academic Information System Users in the State Polytechnic of Sriwijaya based on organizational culture variables and the quality of the information system to the satisfaction of information system users and their implications for employee performance. Data analysis involves 71 participants who come from education personnel with variations in Gender, Age, Latest Education and Years of Service. Data analysis uses CFA of Exogenous and Endogenous Constructions and SEM Partial Least Square (PLS). The final results obtaine conclusion that Organizational Culture Variables have a positive and it do not have significant effect on the satisfaction towards the use of Information Systems while the Quality of Information Systems variable has a positive and significant effect on the Satisfaction towards the Use of Information Systems of State Polytechnic of Sriwijaya Palembang.

Keywords - CIO, User Satisfaction, Information System Management

\section{PENDAHULUAN}

\subsection{Latar Belakang}

Saat ini teknologi informasi (TI) menjadi bagian yang tidak terpisahkan dalam pengelolaan suatu institusi. Peranan TI dalam pengelolaan menitikberatkan pada pengaturan sistem informasi yang terkomputerisasi [1]. Khususnya dalam Perguruan Tinggi, penggunaan TI memberikan dampak peningkatan dalam layanan, transparansi data serta mendukung dalam proses pengambilan kebijakan. Dalam dunia pendidikan atau Perguruan 
JURNAL NUANSA INFORMATIKA

Volume 14 Nomor 2, Juli 2020

Tinggi, sistem informasi yang terkomputerisasi lebih dikenal dengan Sistem Informasi Akademik [2]. Pada umumnya, layanan dalam Sistem Informasi Akademik meliputi layanan kemahasiswaan, penjadwalan bagi dosen dan mahasiswa, layanan bagi dosen, serta monitoring kegiatan akademik bagi pimpinan. Pengembangan pengolaan layanan sistem informasi menjadi faktor kunci keberhasilan suatu Perguruan Tinggi dalam pemanfaatan TI secara optimal [3]. Dalam implementasinya, Sistem Informasi haruslah dapat mengakomodasi kebutuhan para stakeholder yang terkait di dalamnya[10]. Indikator penilaian dalam meninjau kualitas dari Sistem Informasi itu sendiri dapat dilakukan melalui beberapa aspek, salah satunya adalah Kepuasan Pengguna / User Satisfaction [8].

Politeknik Negeri Sriwijaya (POLSRI) merupakan salah satu perguruan tinggi vokasi yang sudah mengimplementasikan Sistem Informasi dalam kegiatan layanan akademik, yang bernama Sistem Informasi Akademik (SISAK). SISAK POLSRI sudah berjalan sejak tahun 2012, dimana dalam sistem ini terdapat beberapa layanan bagi mahasiswa, dosen dan pimpinan, yakni:

a. Akademik Perkuliahan yang meliputi absensi dosen dan mahasiswa, informasi penjadwalan dan perkuliahan

b. Perhitungan honorarium mengajar dosen dan tenaga praktisi

c. Monitoring dan validasi data oleh pimpinan, mahasiswa dan pengadministrasi jurusan

d. Fasilitas laporan akademik

Dalam perjalannya, terutama pada awal pengembangan sistem, SISAK POLSRI mengalami beberapa penyesuaian yang disesuaikan dengan
p-ISSN : 1858-3911, e-ISSN : 2614-5405

https://journal.uniku.ac.id/index.php/ilkom

kebutuhan user, baik dari pimpinan, dosen maupun mahasiswa. Sehingga selaras dengan optimalisasi layanan akademik yang ada di POLSRI. Dalam penelitian yang akan dilakukan ini akan menilai bagaimana kualitas SISAK POLSRI dilihat dari beberapa aspek manajemen, yakni Budaya Organisasi, kualitas Sistem Informasi dan Bagaimana Implikasinya terhadap Kinerja Pegawai.

Pada penelitian sebelumnya dilakukan penilaian terhadap kualitas layanan website E-Commerce terhadap kepuasan pengguna menggunakan metode webqual 4.0. Dalam penelitian ini penilaian dilakukan dengan 347 responden dengan website yang diteliti antara lain: BukaLapak, Tokopedia dan Lazada. Hasil akhir dari penelitian ini berupa penilaian website terbaik, yakni Bukalapak dengan aspek penilaian kategori usability $(0,70)$, Information Quality (0.70) dan Service Interaction Quality (0.65) [4].

Penelitian lainnya berfokus pada pengaruh kualitas sistem, kualitas informasi, dan kualitas layanan terhadap penggunaan sistem e-learning di program pascasarjana Universitas Mercu Buana. Dalam penelitian ini penilaian dilakukan dengan metode GSCA (Generalized Structured Component Analysis) hasil kesimpulan didapatkan bahwa semakin baik persepsi kualitas sistem akan semakin meningkatkan penggunaan sistem e-learning [5].

Selanjutnya pada penelitian lain dengan judul Pengaruh Kualitas Sistem, Kualitas Informasi, Kualitas Pelayanan Rail Ticketing System (RTS) Terhadap Kepuasan Pengguna menitikberatkan pada kualitas Sistem Informasi dalam layanan Rail Ticketing System (RTS) dengan kriteria responden pembeli tiket yang langsung membeli tiket di loket kereta api tanpa melalui pihak ketiga 
JURNAL NUANSA INFORMATIKA

Volume 14 Nomor 2, Juli 2020

(Seperti bank atau gerai minimarket) berjumlah 80 sampel. Hasil akhir dari penelitian ini didapatkan bahwa kualitas informasi, layanan dan sistem memiliki tren positif terhadap persepsi kepuasan user.

Adapun dalam penelitian yang dilakukan akan mengembangkan dari penelitian sebelumnya yang menguji faktor-faktor yang mempengaruhi kepuasan pengguna sistem informasi. Sehingga dapat menjadi masukan terhadap pengembangan SISAK POLSRI secara berkelanjutan. Parameter penilaian kepuasan pengguna sistem informasi dilakukan dengan melihat dari sisi manajemen, yakni bagaimana pengaruh budaya organisasi dan kualitas sistem informasi terhadap kepuasan pengguna sistem informasi dan implikasinya terhadap kinerja pegawai.

\subsection{Identifikasi Masalah}

Berdasarkan uraian latar belakang sebelumnya, identifikasi permasalahan dalam penelitian ini adalah :

a. Seberapa besar pengaruh budaya organisasi dan kualitas sistem informasi secara bersama-sama terhadap kepuasan pengguna sistem informasi.

b. Seberapa besar pengaruh budaya organisasi terhadap kepuasan pengguna sistem informasi

c. Seberapa besar pengaruh kualitas sistem informasi terhadap kepuasan pengguna sistem informasi

d. Seberapa besar pengaruh kepuasan pengguna sistem informasi terhadap kinerja karyawan

\subsection{Tujuan Penelitian}

Adapun tujuan dari penelitian ini adalah:

a. Untuk mengukur besarnya pengaruh Budaya Organisasi dan Kualitas Sistem Informasi secara
p-ISSN : 1858-3911, e-ISSN : 2614-5405

https://journal.uniku.ac.id/index.php/ilkom

bersama-sama terhadap kepuasan pengguna Sistem Informasi.

b. Untuk mengukur besarnya pengaruh Budaya Organisasi dan Kualitas Sistem Informasi terhadap Kinerja Pegawai.

c. Untuk mengukur besarnya pengaruh budaya organisasi dan Kualitas Sistem Informasi terhadap kepuasan pengguna sistem informasi dan implikasinya terhadap kinerja pegawai.

\subsection{Ruang Lingkup}

Agar penelitian ini lebih terarah dan tidak menyimpang dari permasalahan yang ada, maka perlu adanya suatu batasan masalah. Batasan masalah dalam penelitian ini yaitu dengan mengukur pengaruh budaya organisasi, kualitas sistem informasi terhadap kepuasan pengguna sistem informasi dan implikasinya terhadap kinerja karyawan.

\section{METODE PENELITIAN}

Metode Penelitian dapat dilihat pada gambar 1 di bawah ini:

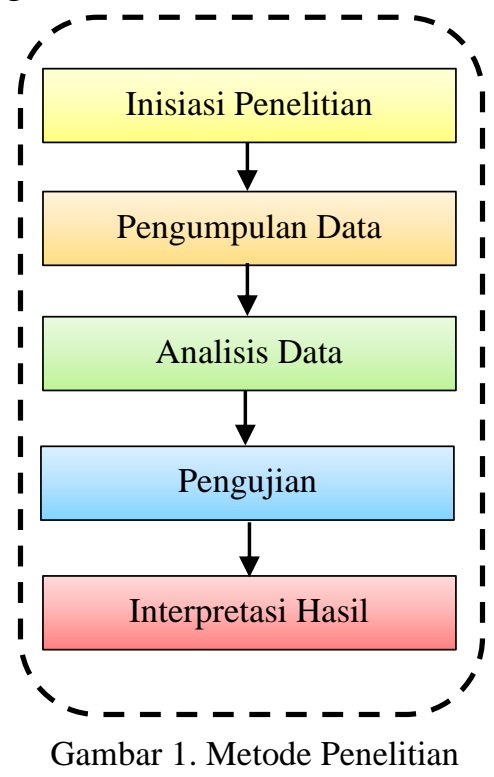

\subsection{Inisiasi Penelitian}

Merupakan tahapan awal dalam penelitian ini dimana objek dan fokus penelitian ditentukan yakni melihat bagaimana kepuasan pengguna Sistem 
JURNAL NUANSA INFORMATIKA

Volume 14 Nomor 2, Juli 2020

Informasi Akademik dalam perspektif manajemen di lingkungan Politeknik Negeri Sriwijaya, jumlah sampel yang diteliti, waktu dan tempat penelitian. Dalam inisiasi penelitian juga menggambarkan apa yang melatarbelakangi penelitian, permasalahan yang terjadi, tujuan dari penelitian itu sendiri serta ruang lingkup penelitian

\subsection{Teknik Pengumpulan Data}

Teknik pengumpulan data yang digunakan dalam melaksanakan penelitian ini adalah sebagai berikut:

a. Studi kepustakaan, yaitu mempelajari buku-buku atau bahanbahan tertulis yang ada hubungannya dengan penelitian yang dilakukan.

b. Studi lapangan, yaitu pengumpulan data yang langsung terjun kelapangan dengan cara observasi, wawancara dan kuesioner.

Teknik pengambilan sampel dilakukan dengan purposive sampling, yaitu sampel ditarik berdasarkan kriteria tertentu. Karakterisitik dari sampel yang akan dijadikan responden dalam penelitian ini yaitu tenaga kependidikan yang berhubungan dengan SISAK POLSRI. Berikut pada tabel 1 menunjukkan data partisipan :

Tabel 1. Daftar Jumlah Pegawai Tenaga Kependidikan di Lingkungan Politeknik Negeri Sriwijaya

\begin{tabular}{|c|l|c|}
\hline No & \multicolumn{1}{|c|}{ Unit Kerja } & $\begin{array}{c}\text { Jumlah } \\
\text { Pegawai }\end{array}$ \\
\hline 1 & Teknik Sipil & 3 \\
\hline 2 & Teknik Mesin & 3 \\
\hline 3 & $\begin{array}{l}\text { Teknik Listrik } \\
\text { Teknik Elektronika } \\
\text { Teknik Telekomunikasi }\end{array}$ & 3 \\
\hline 4 & Teknik Kimia & 3 \\
\hline 5 & Teknik Komputer & 3 \\
\hline 6 & Akuntansi & 3 \\
\hline 7 & Administrasi Bisnis & 3 \\
\hline 8 & $\begin{array}{l}\text { Manajamemen } \\
\text { Informatika }\end{array}$ & 3 \\
\hline 9 & Bahasa Inggris & 3 \\
\hline
\end{tabular}

p-ISSN : 1858-3911, e-ISSN : 2614-5405

https://journal.uniku.ac.id/index.php/ilkom

\begin{tabular}{|c|l|c|}
\hline No & \multicolumn{1}{|c|}{ Unit Kerja } & $\begin{array}{c}\text { Jumlah } \\
\text { Pegawai }\end{array}$ \\
\hline 10 & UPT Perpustakaan & 5 \\
\hline 11 & $\begin{array}{l}\text { UPT Perawatan dan } \\
\text { Perbaikan }\end{array}$ & 5 \\
\hline 12 & $\begin{array}{l}\text { Bagian Administrasi } \\
\text { Umum dan Keuangan }\end{array}$ & 3 \\
\cline { 2 - 3 } & $\begin{array}{l}\text { - Subbagian Tata } \\
\text { Usaha }\end{array}$ & 5 \\
\cline { 2 - 3 } & $\begin{array}{l}\text { - Subbagian } \\
\text { Kepegawaian }\end{array}$ & 7 \\
\hline 13 & $\begin{array}{l}\text { Bagian Administrasi } \\
\text { Akademik dan } \\
\text { Kemahasiswaan }\end{array}$ & $\begin{array}{l}\text { - Subbagian Akademik } \\
\text { dan Kemahasiswaan }\end{array}$ \\
\cline { 2 - 3 } & $\begin{array}{l}\text { - Subbagian } \\
\text { Perencanaan } \\
\text { Sistem Informasi }\end{array}$ & $\mathbf{7 1}$ \\
\hline \multirow{2}{*}{ Jumlah } & 5 \\
\hline
\end{tabular}

\subsection{Teknik Analisis}

Teknis analisis data yang digunakan dalam penelitian ini SEMPLS. PLS-PM merupakan jenis structural equation model (SEM) berbasis komponen dengan sifat konstruk formatif [6]. Tujuan utama PLS-PM adalah menjelaskan hubungan antar konstrak dan menekankan pengertian tentang nilai hubungan tersebut [7].

\subsection{Metode Pengujian Data}

Apabila data-data telah memenuhi syarat setelah melakukan evaluasi atas model pengukuran (measurement model), maka tahap berikutnya adalah melakukan evaluasi terhadap structural model, yaitu tahap pengujian hipotesis untuk mendapatkan hasil apakah signifikan atau tidaknya pengaruh variabel exogen terhadap endogen melalui pengujian:(1) Path coefficients, (2) t-statistics, (3) $F$ squared value [7].

\subsection{Interpretasi Hasil}

Setelah mendapatkan nilai koefisien jalur, tahap selanjutnya adalah membuat interpretasi atas nilai koefisien jalur dari setiap variabel penelitian 
JURNAL NUANSA INFORMATIKA

Volume 14 Nomor 2, Juli 2020

untuk mengetahui besarnya hubungan antar variabel yang digunakan dalam penelitian [9]. Untuk tujuan analisa, interpretasi atas hasil pengujian koefisien jalur yang telah diperoleh untuk setiap variabel akan menggunakan kriteria pada tabel 2 berikut :

Tabel 2. Kriteria Penilaian Hubungan antar Variabel Penelitian Berdasarkan Nilai Koefisien Jalur

\begin{tabular}{|c|c|l|}
\hline No & $\begin{array}{c}\text { Nilai } \\
\text { Koefisien } \\
\text { Jalur }\end{array}$ & \multicolumn{1}{|c|}{ Kriteria Korelasi } \\
\hline 1 & $\begin{array}{c}\text { Less than } \\
0,20\end{array}$ & $\begin{array}{l}\text { Slight correlation, almost } \\
\text { negligible relationship }\end{array}$ \\
\hline 2 & $0,20-0,40$ & $\begin{array}{l}\text { Low correlation, definite } \\
\text { but small relationship }\end{array}$ \\
\hline 3 & $0,40-0,70$ & $\begin{array}{l}\text { Moderate correlation, } \\
\text { substantial relationship }\end{array}$ \\
\hline 4 & $0,70-0,90$ & $\begin{array}{l}\text { High correlation, marked } \\
\text { relationship }\end{array}$ \\
\hline 5 & $0,90-1.00$ & $\begin{array}{l}\text { Very high correlation, } \\
\text { very dependable } \\
\text { relationship }\end{array}$ \\
\hline
\end{tabular}

\section{HASIL DAN PEMBAHASAN}

Responden pada penelitian ini adalah Pegawai Politeknik Negeri Sriwijaya Palembang yang berjumlah 71 Orang. Dari penyebaran kuesioner yang dilakukan, Secara umum pengelompokan responden dalam penelitian ini menurut Jenis Kelamin, Usia, Pendidikan Terakhir dan Masa
p-ISSN : 1858-3911, e-ISSN : 2614-5405

https://journal.uniku.ac.id/index.php/ilkom

Kerja :

Tabel 3. Berdasarkan Jenis Kelamin

\begin{tabular}{|c|c|c|c|}
\hline No & $\begin{array}{c}\text { Jenis } \\
\text { Kelamin }\end{array}$ & $\begin{array}{c}\text { Jumlah } \\
\text { (Orang) }\end{array}$ & $\begin{array}{c}\text { Persentase } \\
(\mathbf{\%})\end{array}$ \\
\hline 1. & Laki-Laki & 37 & $52,12 \%$ \\
\hline 2. & Perempuan & 34 & $47,88 \%$ \\
\hline \multicolumn{2}{r|}{ Total } & $\mathbf{7 1}$ & $\mathbf{1 0 0}$ \\
\hline
\end{tabular}

Tabel 4. Berdasarkan Usia

\begin{tabular}{|c|c|c|c|}
\hline No & Usia & $\begin{array}{c}\text { Jumlah } \\
\text { (Orang) }\end{array}$ & $\begin{array}{c}\text { Persentase } \\
(\mathbf{\%})\end{array}$ \\
\hline 1. & $\begin{array}{c}<25 \\
\text { Tahun }\end{array}$ & 0 & 0 \\
\hline 2. & $\begin{array}{c}25-35 \\
\text { Tahun }\end{array}$ & 35 & $49,30 \%$ \\
\hline 3. & $\begin{array}{c}36-45 \\
\text { Tahun }\end{array}$ & 20 & $28,17 \%$ \\
\hline 4. & $\begin{array}{c}46-55 \\
\text { Tahun }\end{array}$ & 16 & $22,54 \%$ \\
\hline 5. & $\begin{array}{c}>55 \\
\text { Tahun }\end{array}$ & 0 & 0 \\
\hline \multicolumn{2}{|c|}{ Total } & $\mathbf{7 1}$ & $\mathbf{1 0 0}$ \\
\hline
\end{tabular}

\subsection{Analisis Deskriptif Data Penelitian}

a. Variabel Budaya Organisasi $\left(\mathrm{X}_{1}\right)$ Hasil data lapangan yang didapat menunjukkan sebagian besar menjawab "setuju" terhadap pernyataanpernyataan tentang Budaya Organisasi yang terdiri dari aspek Attention to Detail, Innovation, Team Orientation, Outcome Orientation. Ringkasan sudut pandang responden terhadap pernyataan-pernyataan tentang Budaya Organisasi terdapat dalam tabel 5:

Tabel 5. Rangkuman Persepsi Responden terhadap Variabel Budaya Organisasi

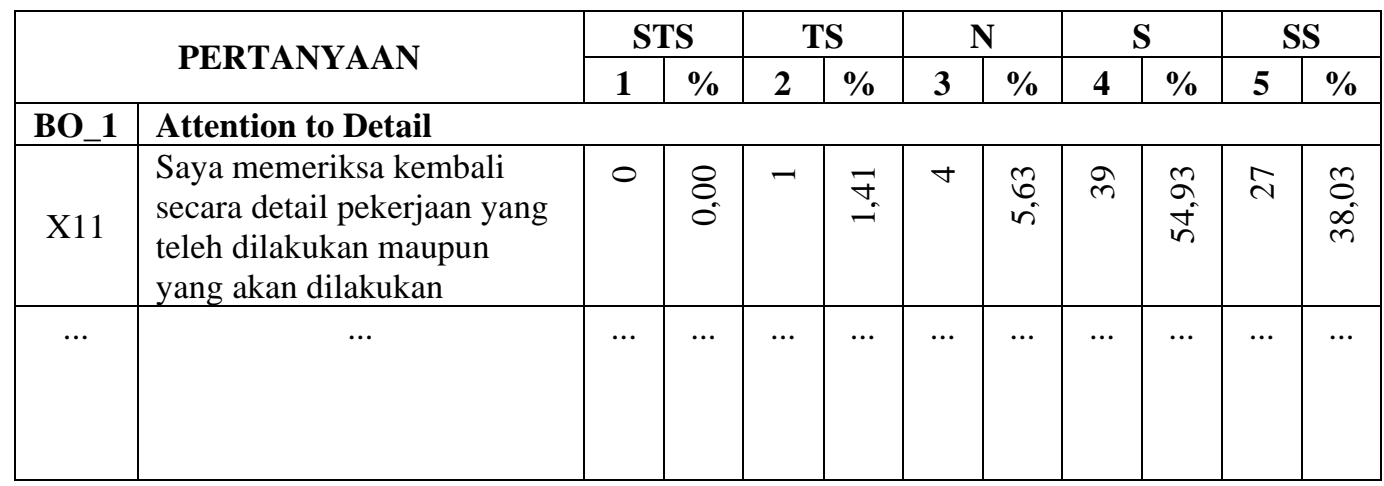




\begin{tabular}{|c|c|c|c|c|c|c|c|c|c|c|c|}
\hline \multirow{2}{*}{\multicolumn{2}{|c|}{ PERTANYAAN }} & \multicolumn{2}{|c|}{ STS } & \multicolumn{2}{|c|}{ TS } & \multicolumn{2}{|c|}{$\mathbf{N}$} & \multicolumn{2}{|c|}{$\mathbf{S}$} & \multicolumn{2}{|c|}{ SS } \\
\hline & & 1 & $\%$ & 2 & $\%$ & 3 & $\%$ & 4 & $\%$ & 5 & $\%$ \\
\hline X110 & $\begin{array}{l}\text { Saya membandingkan } \\
\text { hasil pekerjaan yang } \\
\text { dilakukan dengan hasil } \\
\text { pekerjaan pihak lain dalam } \\
\text { mencapai target kerja yang } \\
\text { menjadi tanggungjawab. }\end{array}$ & 0 & $\begin{array}{l}8 \\
0 \\
0\end{array}$ & 6 & $\begin{array}{l}\stackrel{n}{+} \\
\infty\end{array}$ & 니 & $\begin{array}{l}\text { రె } \\
\text { లో }\end{array}$ & $\lesssim$ & $\begin{array}{l}\infty \\
\infty \\
\infty \\
m\end{array}$ & $\simeq$ & ̊̊ \\
\hline
\end{tabular}

b. Variabel Kualitas Sistem

Informasi (X2)

Hasil dari data lapangan yang didapat menunjukkan sebagian besar menjawab "setuju" terhadap pernyataan-pernyataan mengenai
Kualitas Sistem Informasi yang terdiri dari domain Integrasi, Fleksibel, Keandalan, Efisien. Ringkasan persepsi responden terhadap pernyataan tentang Kualitas Sistem Informasi pada tabel 6 berikut :

Tabel 6. Rangkuman Persepsi Responden terhadap Variabel Kualitas Sistem Informasi

\begin{tabular}{|c|c|c|c|c|c|c|c|c|c|c|c|}
\hline \multirow{2}{*}{\multicolumn{2}{|c|}{ PERTANYAAN }} & \multicolumn{2}{|c|}{ STS } & \multicolumn{2}{|c|}{ TS } & \multicolumn{2}{|c|}{$\mathbf{N}$} & \multicolumn{2}{|c|}{$\mathbf{S}$} & \multicolumn{2}{|c|}{ SS } \\
\hline & & 1 & $\%$ & 2 & $\%$ & 3 & $\%$ & 4 & $\%$ & 5 & $\%$ \\
\hline KSI_1 & Integrasi & & & & & & & & & & \\
\hline $\mathrm{X} 21$ & $\begin{array}{l}\text { Kualitas SI yang saya } \\
\text { gunakan saat ini menyatu } \\
\text { (terpadu) dengan bagian } \\
\text { yang lain di kantor } \\
\text { setempat (software, } \\
\text { hardware dan jaringan } \\
\text { menyatu), sehingga mudah } \\
\text { mengakses data yang } \\
\text { diperlukan. }\end{array}$ & 0 & $\underset{0}{8}$ & 0 & $\underset{0}{8}$ & $\simeq$ & $\begin{array}{l}\text { §ิ } \\
6\end{array}$ & 寸 & $\hat{\sigma}$ & $\underline{n}$ & $\stackrel{m}{\Rightarrow}$ \\
\hline$\ldots$ & $\ldots$ & $\ldots$ & $\cdots$ & $\ldots$ & ... & ... & ... & $\ldots$ & $\ldots$ & ... & $\ldots$ \\
\hline $\mathrm{X} 216$ & $\begin{array}{l}\text { Untuk setiap pekerjaan } \\
\text { yang saya lakukan, telah } \\
\text { ditetapkan waktu } \\
\text { penyelesaiannya. }\end{array}$ & 0 & $\underset{0}{8}$ & $\infty$ & $\underline{\triangleq}$ & 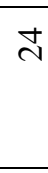 & $\begin{array}{l}\infty \\
\stackrel{\infty}{m}\end{array}$ & $\approx$ & $\begin{array}{l}\vec{\sim} \\
\stackrel{n}{n}\end{array}$ & $\Xi$ & $\frac{1}{2}$ \\
\hline
\end{tabular}

c. Variabel Kepuasan Penggunaan

Sistem Informasi (Y)

Hasil data lapangan yang didapat menunjukkan mayoritas menjawab "setuju" terhadap pernyataanpernyataan tentang Kepuasan
Penggunaan Sistem Informasi yang Ringkasan sudut pandang responden terhadap pernyataan mengenai Kepuasan Penggunaan Sistem Informasi pada tabel 7 berikut :

Tabel 7. Rangkuman Persepsi Responden terhadap Variabel Kepuasan Penggunaan Sistem Informasi

\begin{tabular}{|c|c|c|c|c|c|c|c|c|c|c|c|}
\hline \multirow{2}{*}{\multicolumn{2}{|c|}{ PERTANYAAN }} & \multicolumn{2}{|c|}{ STS } & \multicolumn{2}{|c|}{ TS } & \multicolumn{2}{|c|}{$\mathbf{N}$} & \multicolumn{2}{|c|}{$\mathbf{S}$} & \multicolumn{2}{|c|}{ SS } \\
\hline & & 1 & $\%$ & 2 & $\%$ & 3 & $\%$ & 4 & $\%$ & 5 & $\%$ \\
\hline KPSI_1 & Kesenangan & & & & & & & & & & \\
\hline $\mathrm{Y} 1$ & $\begin{array}{l}\text { Fitur-fitur sistem informasi } \\
\text { yang digunakan saat ini } \\
\text { dirancang memberikan } \\
\text { keyamanan kepasa saya dalam } \\
\text { menggunakan sistem aplikas }\end{array}$ & 0 & $\stackrel{8}{\circ}$ & 0 & $\begin{array}{l}8 \\
0 \\
0\end{array}$ & N & $\begin{array}{l}\text { N } \\
\text { Ni }\end{array}$ & f & 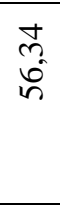 & શิ & $\begin{array}{l}n \\
\infty \\
\delta \\
f\end{array}$ \\
\hline$\ldots$ & $\ldots$ & $\ldots$ & $\ldots$ & $\ldots$ & $\ldots$ & $\ldots$ & $\ldots$ & $\ldots$ & & & \\
\hline
\end{tabular}




\begin{tabular}{|c|c|c|c|c|c|c|c|c|c|c|c|}
\hline & \multirow{2}{*}{ PERTANYAAN } & \multicolumn{2}{|c|}{ STS } & \multicolumn{2}{|c|}{ TS } & \multicolumn{2}{|c|}{$\mathbf{N}$} & \multicolumn{2}{|c|}{$\mathbf{S}$} & \multicolumn{2}{|c|}{ SS } \\
\hline & & 1 & $\%$ & 2 & $\%$ & 3 & $\%$ & 4 & $\%$ & 5 & $\%$ \\
\hline Y7 & $\begin{array}{l}\text { Saya puas dengan relevansi } \\
\text { laporan yang dihasilkan } \\
\text { sistem informasi dalam } \\
\text { mengambil keputusan sesuai } \\
\text { dengan wewenang dan } \\
\text { tanggung jawab }\end{array}$ & 0 & $\stackrel{8}{8}$ & 0 & $\begin{array}{l}8 \\
0 \\
0\end{array}$ & $r$ & $\begin{array}{l}\infty \\
\infty\end{array}$ & in & 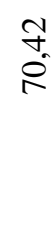 & \pm & $\frac{N}{2}$ \\
\hline
\end{tabular}

d. Variabel Kinerja Pegawai (Z)

Hasil data lapangan yang didapat menunjukkan mayoritas responden menjawab "setuju" terhadap pernyataan-pernyataan tentang Kinerja Pegawai yang terdiri dari domain Kuantitas Kerja, Kualitas Kerja,
Pengetahuan Pekerjaan, Kreatifitas, Kerjasama, Ketergantungan, Inisiatif, Kualitas Personal. Ringkasan sudut pandang responden terhadap pernyataan tentang variabel Kinerja Pegawai pada tabel 8:

Tabel 8. Rangkuman Persepsi Responden terhadap Variabel Kinerja Pegawai

\begin{tabular}{|c|c|c|c|c|c|c|c|c|c|c|c|}
\hline \multirow{2}{*}{\multicolumn{2}{|c|}{ PERTANYAAN }} & \multicolumn{2}{|c|}{ STS } & \multicolumn{2}{|c|}{ TS } & \multicolumn{2}{|c|}{$\mathbf{N}$} & \multicolumn{2}{|c|}{$\mathbf{S}$} & \multicolumn{2}{|c|}{ SS } \\
\hline & & 1 & $\%$ & 2 & $\%$ & 3 & $\%$ & 4 & $\%$ & 5 & $\%$ \\
\hline KK_1 & Kuantitas Kerja & & & & & & & & & & \\
\hline $\mathrm{Z1}$ & $\begin{array}{l}\text { Saya memiliki kemampuan } \\
\text { menyelesaikan tugas sesuai } \\
\text { dengan standar kerja yang } \\
\text { ada }\end{array}$ & 0 & $\stackrel{8}{8}$ & 0 & $\begin{array}{l}8 \\
0 \\
0\end{array}$ & $n$ & 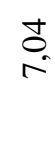 & to & $\begin{array}{l}\frac{R}{R} \\
\text { ti }\end{array}$ & กิ & $\stackrel{\text { I }}{\infty}$ \\
\hline$\ldots$ & $\ldots$ & $\ldots$ & $\ldots$ & $\ldots$ & $\ldots$ & $\ldots$ & $\ldots$ & $\ldots$ & $\ldots$ & $\ldots$ & $\ldots$ \\
\hline Z16 & $\begin{array}{l}\text { Saya memiliki integritas } \\
\text { pribadi yang kuat }\end{array}$ & 0 & ஜ & 0 & $\stackrel{8}{\circ}$ & 6 & $\stackrel{n}{+\infty}$ & F & $\frac{n}{n}$ & $\stackrel{む}{\sim}$ & $\begin{array}{l}\infty \\
\infty\end{array}$ \\
\hline
\end{tabular}

3.2. Confirmatory Factor Analysis (CFA) Konstruk Eksogen dan Endogen

Pengukuran model (measurement model) untuk menguji validitas dan reliabilitas dari indikatorindikator pembentuk konstruk laten dilakukan dengan analisis faktor konfirmatori (CFA). Pada Model_1 CFA Konstruk Eksogen (Budaya Organisasi, Kualitas Sistem Informasi) dan Endogen (Kepuasan Penggunaan Sistem Informasi, Kinerja Pegawai)

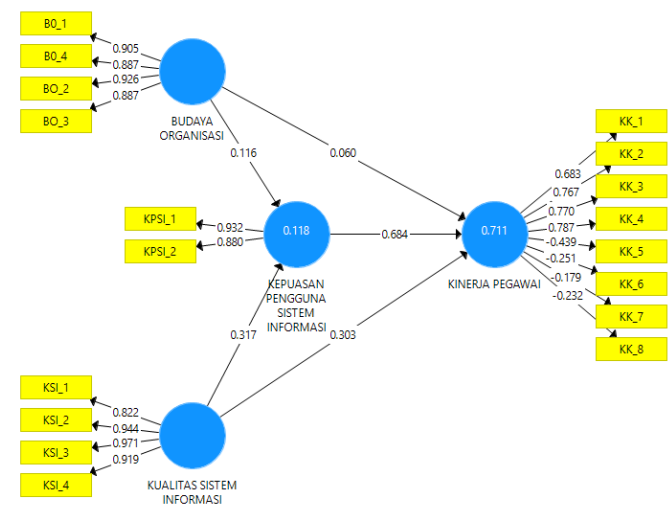

Gambar 2. Uji CFA_1 Eksogen dan Endogen

Berdasarkan Gambar 2 Uji CFA Eksogen dan Endogen, untuk uji CFA Eksogen pada variabel Budaya Organisasi $\left(\mathrm{X}_{1}\right)$, Kualitas Sistem Informasi $\left(\mathrm{X}_{2}\right)$ dan uji CFA Endogen pada variabel Kepuasan Pengguna 
Sistem Informasi (Y)tidak terdapat nilai muatan faktor loading $<0,5$. Sedangkan uji CFA Endogen pada Variabel Kinerja Pegawai (Z) masih terdapat loading yang < 0,5 yaitu indikator KK_6, KK_7, dan KK_8, artinya indikator tersebut belum valid dan harus dikeluarkan, sehingga diperoleh Model_2 CFA Konstruk Eksogen dan Endogen:

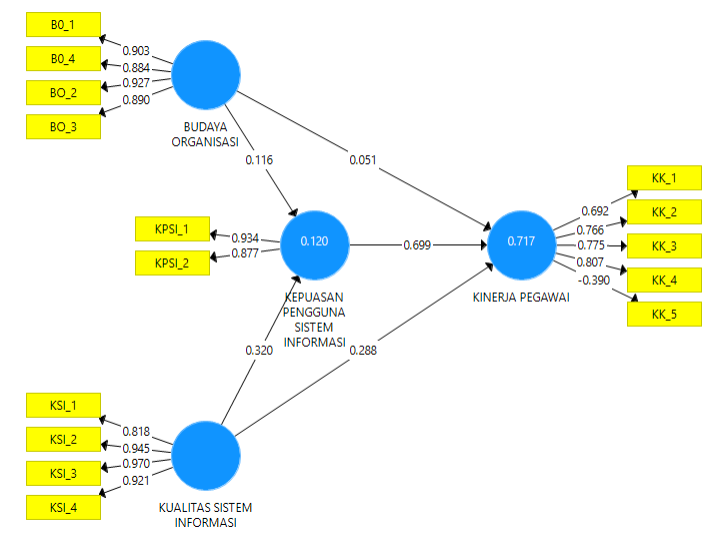

Gambar 3 Uji CFA_2 Eksogen dan Endogen

Berdasarkan Gambar 3 Uji CFA Eksogen dan Endogen, untuk uji CFA Endogen Kinerja Pegawai (Z) masih terdapat loading yang $<0,5$ yaitu indikator KK_5, artinya indikator tersebut belum valid dan harus dikeluarkan, sehingga diperoleh Model_3 CFA Konstruk Eksogen dan Endogen:
p-ISSN : 1858-3911, e-ISSN : 2614-5405

https://journal.uniku.ac.id/index.php/ilkom

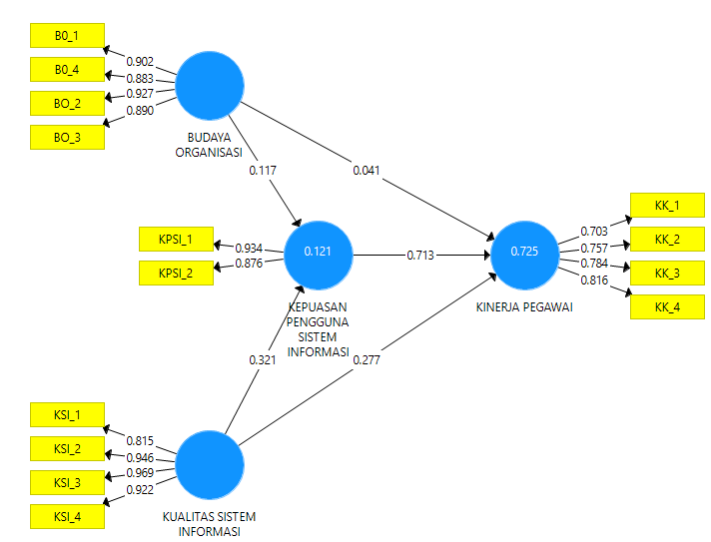

Gambar 4 Uji CFA_3 Eksogen dan Endogen

Berdasarkan Gambar 4 Uji CFA_3 Eksogen dan Endogen, pada variabel Kinerja Pegawai (Z) sudah tidak terdapat nilai muatan faktor loading < 0,5 . Sehingga semua indikator pada Konstruk eksogen Pada Variabel Budaya Organisasi dan Kualitas Sistem Informasi serta Konstruk Endogen pada Variabel Kepuasan Penggunaan Sistem Informasi dan Kinerja Pegawai sudah menunjukkan valid. Hasil perhitungan reliabilitas dengan Composite Reliability dari Analisis Faktor Konfirmatori / CFA variabel eksogen dam Endogen juga menunjukkan seluruh varibel penelitian dalam full model memiliki reliabilitas yang baik.

Tabel 9. Nilai Loading Factor dan Composite Reliability Eksogen

\begin{tabular}{|c|c|c|c|c|}
\hline Variabel & Konstruk & $\begin{array}{c}\text { Loading factor } \\
(>0,5)\end{array}$ & $\begin{array}{c}\text { Composite } \\
\text { Reliability }(>0,7) \\
\end{array}$ & Keterangan \\
\hline \multirow[t]{4}{*}{ Budaya Organisasi $\left(\mathbf{X}_{1}\right)$} & BO_1 & 0,902 & \multirow[t]{4}{*}{0,945} & Valid \& Reliabel \\
\hline & BO $\_2$ & 0,883 & & Valid \& Reliabel \\
\hline & BO_3 & 0,927 & & Valid \& Reliabel \\
\hline & BO_4 & 0,890 & & Valid \& Reliabel \\
\hline \multirow{4}{*}{$\begin{array}{l}\text { Kualitas Sistem } \\
\text { Informasi } \\
\left(\mathbf{X}_{2}\right)\end{array}$} & KSI_1 & 0,667 & \multirow[t]{4}{*}{0,954} & Valid \& Reliabel \\
\hline & KSI_2 & 0,816 & & Valid \& Reliabel \\
\hline & KSI_3 & 0,581 & & Valid \& Reliabel \\
\hline & KSI_4 & 0,810 & & Valid \& Reliabel \\
\hline \multirow{2}{*}{$\begin{array}{l}\text { Kepuasan Penggunaan } \\
\text { Sistem Informasi (Y) }\end{array}$} & KPSI_1 & 0,934 & \multirow[t]{2}{*}{0,901} & Valid \& Reliabel \\
\hline & KPSI_2 & 0,876 & & Valid \& Reliabel \\
\hline \multirow{4}{*}{$\begin{array}{l}\text { Kinerja Pegawai } \\
\text { (Z) }\end{array}$} & KK_1 & 0,703 & \multirow[t]{4}{*}{0,850} & Valid \& Reliabel \\
\hline & KK_2 & 0,757 & & Valid \& Reliabel \\
\hline & KK_3 & 0,784 & & Valid \& Reliabel \\
\hline & KK_4 & 0,816 & & Valid \& Reliabel \\
\hline
\end{tabular}


JURNAL NUANSA INFORMATIKA

Volume 14 Nomor 2, Juli 2020

Berdasarkan Tabel 9 diatas menunjukkan bahwa semua indikator pada variabel Eksogen dan Endogen sudah menunjukkan valid. Hasil perhitungan reliabilitas dengan Composite Reliability variabel eksogen dan endogen juga menujukkan bahwa variabel Budaya Organisasi, Kualitas Sistem Informasi, Komitmen dan Kinerja Pegawai dalam full model memiliki reliabilitas yang baik sehingga dapat dianalisis lebih lanjut.

\subsection{Analisis Partial Least Square}

Analisis selanjutnya adalah analisis Partial Least Square (PLS) secara full model (tanpa melibatkan indikator yang tidak valid). Berikut pada Gambar 4.3 adalah hasil PLS.

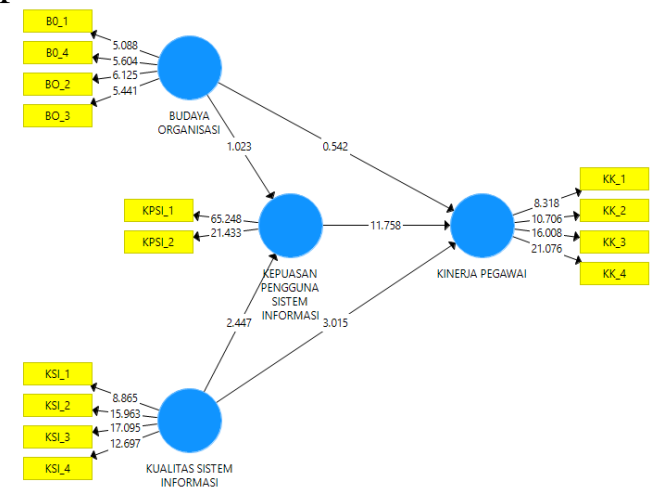

Gambar 5 Model Hasil PLS
p-ISSN : 1858-3911, e-ISSN : 2614-5405

https://journal.uniku.ac.id/index.php/ilkom

Untuk memvalidasi model secara keseluruhan, maka digunakan goodness of fit $(\mathrm{GoF})$. GoF index ini merupakan ukuran tunggal yang digunakan untuk memvalidasi performa gabungan antara model pengukuran (outer model) dan model structural (inner model). Nilai GoF index ini diperoleh dari averages communalities index dikalikan dengan $\mathrm{R}^{2}$ model.

GoF $=\sqrt{\overline{\operatorname{Com}} \times \bar{R}^{2}}$

$G o F=\sqrt{0,912 \times 0,725}$

GoF $=0,69$

Pada hasil perhitungan menunjukan nilai goodness of fit $(\mathrm{GoF})$ baik yaitu sebesar 0,69.

b. Resampling Bootstraping

Berdasarkan tujuan-tujuan penelitian, maka rancangan uji hipotesis yang dapat dibuat merupakan rancangan uji hipotesis dalam penelitian ini disajikan berdasarkan tujuan penelitian. Tingkat kepercayaan yang digunakan adalah 95\%, sehingga tingkat presisi atau batas ketidakakuratan sebesar $(\alpha)=5 \%=$ 0,05. Dan menghasilkan nilai t- tabel sebesar 1.96, sehingga:

a. Uji Kecocokan Goodness of Fit Index

Tabel 10. Nilai koefisien dan t-hitung pada taraf $5 \%$

\begin{tabular}{|l|c|c|c|l|}
\hline \multicolumn{1}{|c|}{ Variabel } & Koefisien & t-hitung (>1,96|) & P Values & Keterangan \\
\hline $\begin{array}{l}\text { Kepuasan Penggunaan Sistem } \\
\text { Informasi -> Kinerja Pegawai }\end{array}$ & 0,713 & 11,758 & 0,000 & Signifikan \\
\hline $\begin{array}{l}\text { Kualitas Sistem Informasi -> Kepuasan } \\
\text { Penggunaan Sistem Informasi }\end{array}$ & 0,321 & 2,447 & 0,015 & Signifikan \\
\hline $\begin{array}{l}\text { Kualitas Sistem Informasi -> Kinerja } \\
\text { Pegawai }\end{array}$ & 0,506 & 4,278 & 0,000 & Signifikan \\
\hline $\begin{array}{l}\text { Budaya Organisasi -> Kepuasan } \\
\text { Penggunaan Sistem Informasi }\end{array}$ & 0,117 & 1,023 & 0,307 & $\begin{array}{l}\text { Tidak } \\
\text { Signifikan }\end{array}$ \\
\hline Budaya Organisasi -> Kinerja Pegawai & 0,125 & 1,064 & 0,288 & $\begin{array}{l}\text { Tidak } \\
\text { Signifikan }\end{array}$ \\
\hline
\end{tabular}

Berdasarkan tabel di atas, maka diperoleh persamaan sebagai berikut:

1. Persamaan Sub-Struktural:

\section{KPSI = 0,117BO + 0,321 KSI}

Berdasarkan model sub struktural dapat dijelaskan bahwa Kepuasan
Penggunaan Sistem Informasi (KPSI) dipengaruhi secara langsung oleh Budaya Organisasi (BO) Dan Kualitas Sistem Informasi (KSI). Hal ini menunjukan bahwa Budaya Organisasi berpengaruh positif terhadap Kepuasan 
JURNAL NUANSA INFORMATIKA

Volume 14 Nomor 2, Juli 2020

Penggunaan Sistem Informasi sebesar 0,117 dan Kualitas Sistem Informasi berpengaruh positif sebesar 0.321 terhadap Kepuasan Penggunaan Sistem Informasi Pegawai Politeknik Negeri Sriwijaya Palembang .

2. Persamaan Struktural:

\section{$\mathrm{KP}=0,506^{*} \mathrm{KPSI}+0,125 * \mathrm{BO}+$ $0,713 *$ KSI}

Berdasarkan model struktural di atas dapat dijelaskan bahwa Kinerja Pegawai dipengaruhi secara langsung oleh Budaya Organisasi (BO), Kualitas Sistem Informasi (KSI) dan Kepuasan Penggunaan Sistem Informasi (KPSI). Besarnya pengaruh Budaya Organisasi

\section{Tabel 11. Pengaruh Langsung dan Tidak Langsung}

\begin{tabular}{|c|c|c|c|c|}
\hline Variabel Bebas & $-->$ & $\begin{array}{l}\text { Variabel } \\
\text { Terikat }\end{array}$ & $\begin{array}{l}\text { Pengaruh } \\
\text { Langsung }\end{array}$ & $\begin{array}{c}\text { Pengaruh } \\
\text { Tidak } \\
\text { Langsung }\end{array}$ \\
\hline Budaya Organisasi & $-\cdots$ & & 1,064 & 0,985 \\
\hline $\begin{array}{ll}\text { Kualitas } & \text { Sistem } \\
\text { Informasi } & \\
\end{array}$ & $-->$ & Kinerja Pegawai & 4,278 & 2,297 \\
\hline
\end{tabular}

Berdasarkan Tabel 11 menunjukkan bahwa nilai koefisien pengaruh langsung Budaya Organisasi terhadap Kinerja Pegawai (1,064), pengaruh tidak langsung $(0,985)$. Nilai koefisien pengaruh langsung Kualitas Sistem Informasi terhadap Kinerja Pegawai $(4,278)$ pengaruh tidak langsung (2,297). Hal tersebut berarti budaya organisasi dan kualitas sistem informasi berpengaruh terhadap kepuasan pengguna sistem informasi dan implikasinya terhadap kinerja pegawai Politeknik Sriwijaya.

\subsection{Pengaruh Budaya Organisasi terhadap Kepuasan Penggunaan Sistem Informasi}

Pengujian Hipotesis menunjukan variabel Budaya Organisasi berpegaruh positif dan tidak signifikan sebesar $1,023 \quad(<1,96)$ terhadap Kepuasan Penggunaan Sistem Informasi Pegawai Politeknik Negeri Sriwijaya Palembang. terhadap Kinerja Pegawai sebesar 0,125, Kualitas Sistem Informasi terhadap Kinerja Pegawai sebesar 0,713, dan Kepuasan Penggunaan Sistem Informasi terhadap Kinerja Pegawai sebesar 0,506. Artinya Kualitas Sistem Informasi mempunyai pengaruh yang lebih besar terhadap Kinerja Pegawai dari pada Budaya Organisasi dan Kepuasan Penggunaan Sistem Informasi pada Pegawai Politeknik Negeri Sriwijaya Palembang.

3. Hasil Pengujian Pengaruh Langsung dan Pengaruh Tidak Langsung
3.5. Pengaruh Kualitas Sistem Informasi terhadap Kepuasan Penggunaan Sistem Informasi

Pengujian Hipotesis menunjukan variabel Kualitas Sistem Informasi berpengaruh positif dan signifikan sebesar 11,758 (>1,96) terhadap Kepuasan Penggunaan Sistem Informasi Pegawai Politeknik Negeri Sriwijaya Palembang.

Penelitian menggunakan variabel usefulness dan ease of use untuk mengukur keberhasilan sistem informasi

\subsection{Pengaruh Budaya Organisasi terhadap Kinerja Pegawai}

Pengujian Hipotesis menunjukan variabel Budaya Organisasi berpengaruh positif dan signifikan sebesar 1,064 $(>1,96)$ terhadap Kinerja Pegawai Politeknik Negeri Sriwijaya Palembang. 
JURNAL NUANSA INFORMATIKA

Volume 14 Nomor 2, Juli 2020
p-ISSN : 1858-3911, e-ISSN : 2614-5405

https://journal.uniku.ac.id/index.php/ilkom

\subsection{Pengaruh Kualitas Sistem Informasi terhadap Kinerja Pegawai}

Pengujian Hipotesis menunjukan variabel Kepuasan Penggunaan Sistem Informasi berpengaruh positif dan signifikan sebesar 2,447 (>1,96) terhadap kinerja pegawai Politeknik Negeri Sriwijaya Palembang.

\subsection{Pengaruh Kepuasan \\ Penggunaan Sistem Informasi terhadap Kinerja Pegawai}

Pengujian Hipotesis menunjukan variabel budaya organisasi berpengaruh positif sebesar 0,985 terhadap kepuasan pengguna sistem informasi dan implikasinya terhadap kinerja pegawai.

\subsection{Pengaruh Budaya Organisasi terhadap Kepuasan Penggunaan Sistem Informasi dan Implikasinya terhadap Kinerja Pegawai}

Pengujian Hipotesis menunjukan variabel Kualitas Sistem Informasi berpengaruh positif sebesar 2,297 terhadap Kepuasan Penggunaan Sistem Informasi dan Implikasinya terhadap Kinerja Pegawai Politeknik Negeri Sriwijaya Palembang

4. SARAN

Untuk meningkatkan kinerja pegawai Politeknik Negeri Sriwijaya Palembang, maka kepuasan pengguna sistem informasi perlu di tingkatkan, karena kepuasan kerja merupakan sikap yang dimiliki oleh seseorang pegawai, sebagai hasil dari persepsi mereka terhadap pekerjaannya. Bagi peneliti selanjutnya, disarankan untuk memperluas sampel sehingga hasil penelitian dapat digeneralisasi. Menambahkan variabel independen lain seperti Lingkungan kerja dan Motivasi.

\section{DAFTAR PUSTAKA}

[1] Husda, N. E. (2018). Analisa Kualitas Pelayanan Sistem Informasi Akademik Terhadap Kepuasan Pengguna Sistem di STMIK Putera Batam. Computer Based Information System Journal, Vol 1, No. 1

[2] Utomo, L. T., Ardianto, Y. T., \& Sisharini, N. (2017). Pengaruh kualitas sistem, kualitas informasi, kualitas layanan, terhadap kepuasan pengguna sistem informasi akademik universitas merdeka malang. Jurnal Teknologi dan Manajemen Informatika, Vol 3, No. 2

[3] Ellyusman, S., \& Hutami, R. F. (2017). Analisis Kualitas Sistem Informasi Akademik Menggunakan Metode Importance Performance Analysis (ipa)(studi Kasus Pada Website I-gracias Universitas Telkom Bandung). eProceedings of Management, 4(2).

[4] Aryadita, H., Widyastuti, D. A., \& Wardani, N. H. (2017). Analisis Kualitas Layanan Website ECommerce Terhadap Kepuasan Pengguna Menggunakan Metode Webqual 4.0. STUDIA INFORMATIKA: JURNAL SISTEM INFORMASI, 10(1).

[5] Purwanto, S. K., \& Pawirosumarto, S. (2017). Pengaruh kualitas sistem, kualitas informasi, dan kualitas layanan terhadap penggunaan sistem e-learning di program pascasarjana Universitas Mercu Buana. Jurnal Manajemen, 21(2), 282-305.

[6] Mustafa, Z., \& Wijaya, T. (2012). Panduan Teknik Statistik SEM \& PLS dengan SPSS Amos. Yogyakarta: Cahaya Atma Pustaka.

[7] Yamin, S., \& Kurniawan, H. (2011). Generasi baru mengolah data penelitian dengan partial least 
JURNAL NUANSA INFORMATIKA

Volume 14 Nomor 2, Juli 2020
p-ISSN : 1858-3911, e-ISSN : 2614-5405

https://journal.uniku.ac.id/index.php/ilkom

square path modeling. Jakarta: Salemba Infotek.

[8] Isa, I. G. T., \& Hadiana, A. (2017). Implementasi Kansei Engineering dalam Perencanaan Desain Interface e-Learning Berbasis Web (Studi Kasus: SMK Negeri 1 Sukabumi). JuTISI: Jurnal Teknik Informatika dan Sistem Informasi, 3(1), 104-115.

[9] Wirahutama, G., \& ADIWIBOWO, A. S. (2011). Ambiguitas Peran sebagai Variabel Moderator terhadap Hubungan antara Kualitas Sistem Informasi dan Kepuasan Pengguna Akhir Software Akuntansi pada DPKAD Kota Semarang. Universitas Diponegoro

[10] Volonino, L., \& Turban, E. (2011). Information Technology for management. In: Danvers: Wiley 